being of the human race that the Committee venture to put forward this appeal for public support. Cheques should be made payable to the London Joint City and Midland Bank, cxossed "\& Co." and marked "The Mackenzie Davidson Memorial Fund," and sent to Dr. liobert Knox, 38, Harley-street,' W. 1.

A. Bonar Law.

$$
\text { We are, sir, yours faithfully, }
$$

STANLEY BALDWIN,

J. J. THOMSON.

ClifFord ALLBUTt.

HUMPHRY D. ROLLESTON.

ALEXANDER OGSTON.

ROBERT HADFIEED.

ROBERT JONES.

J. Y. W. MACALISTER.

A. E. Barclay.

THOMAS J. HORDER.

N. S. FINZI.

G. HARRISON ORTON.

LENNOX WAINWRIGHT.

G. W. C. KAYE.

CHRIsTOPHER ADDISON.

HARCOURT.

BERTRAND DAWSON.

W. D. CoOLIDGE.

IV. WATSON CHFYNE.

Frederick W. MOTT.

ANDERSON CRITGHETT.

ERNEST RUTHERFORD.

Charles H. WORDINGHaM. ARCHIBALD D. REID.

C. Thurstan HoLLAND. SIDNEY RUSS.

W. IRONSIDE BRUCE.

GILBERT SCOTT. ROBERT KNOX.

\section{BLIND MASSEURS.}

To the Editor of THE LANCET.

SIR,-In THE LANCET of Feb. 21st is an annotation referring to blind masseurs. In the concluding paragraph thereof the opinion is expressed that a blinded masseur is incapable of giving effective remedial exercise and re-education treatment. To this opinion I wish to take very strong exception.

Considerable experience of blinded masseurs, who have also been trained to apply remedial exercises and to re-educate muscles, has convinced me that with careful and adequate preparation there is no reason whatever why a blind masseur or masseuse should not be able to apply any of the remedial exercises described by Kleen, Wide, or any other disciple of Ling ( $\mathrm{I}$ write as one who was trained in this method of treatment in Stockholm). As a further proof, I may mention the fact that a member of the Association of Certificated Blind Massc $_{x z}$ rs passed the full examination conducted by the Incorporated Society of Trained Masseuses, qualifying for the certificate in "Swedish remedial exercises," and came out first in the list, although he was the only blind examinee! I consider that the paragraph referred to is calculated to affect adversely the prospects of a very deserving, enthusiastic, and capable band of workers, worthy of every possible help and fair treatment. I disagree entirely with the statement that "the blind administrator will be tempted to mete out to patients inferior treatment."

I state with conviction that if a blind masseur has been properly trained his treatment will not be inferior to that of an administrator gifted with sight.

I am, Sir, yours faithfully,

W. H. BRoAD, M.D., Major, R.A.M.C.,

Lately O.I.C., Physical Treatment Department, Alder Hey

Liverpool, Feb. 25th, 1920.

To the Editor of THE LANCET.

SrR, - Many thanks for your generous reference to the Association of Certificated Blind Masseurs in your issue of Feb. 21st. In regard to the final paragraph our men go through a specially prepared course of remedial exercises, but I quite agree with you that perfection in these is out of the reach of the blind practitioner.

I am, Sir, yours faithfully,

\section{ARTHUR PEARSON,}

Feb. 26th, 1920

\section{Chairman, Blinded Soldiers'}

$$
\begin{aligned}
& \text { Blinded Soldiers' } \\
& \text { Care Committee. }
\end{aligned}
$$

\section{A PROFESSOR OF MILITARY MEDICAL HISTORY} FOR OUR INDIAN WARS.

\section{To the Editor of THE LANCE'.}

SIR,-A letter from Major-General Sir G. J. H. Evatt, A.M.S., in youx issue of Jan. 31st, contains the valuable suggestion that a medical history of our Indian war's should be compiled. I am in entire agreement with him in this, as I have from time to time luring the last quartor of a contury oxperiencol the greatest difficulty in collecting data on the subject. The same suggestion was put forward in lily" "Pl'vention of Disease and Inefficioncy, with Sinecial Lef'rence to Indian Frontiel Warfare," second adition, 1911. 'J'he recolds from which such a history could bo rompiled are seattered in a host of files in various detrartments in simla and in the old files stored in Calcutta. Some usoful information on the subject is also to be found in that delightenl and charmingly witten work, "Fistory of the Indian Meclical Service," two volmmes, ly Licutenant-Colonel D. G. Craw ford, I.M.S. ('I'hacker. Sintink and Co., Calcutta). For the compilation of such a history I would suggest that a senior major or junior licutenant-colonel of the I.M.S. with a talent for collectins and arransing historical facts be selected, and placed on special duty for the purpose for six months.

I do not see my way to aspeeing with General Evatt's further suggestion that "Military Medical History for" our Indian Wars", should be made the subject of a professorship. I greatly doubt if the material available would be sufficiently entensive to justify this. It could, however, be most profitably included in some other professorship such as one dealing with medical organisation and administration in the field.

One earnestly hopes that in the near future a military medical school will be opened in India and that the matter under reference will receive due consideration in connexion with it.

$$
\text { I am, Sir, yours faithfully, }
$$

$$
\text { P. HEHIR, }
$$

London, March 1st, 1920. Major-General. I.M.S.

\section{ARTIFICIAL SPIROCHETES.}

To the Editor of THE LANCET.

SIR,-It may interest those who have been concerned in recent years with the motile "streamers" which exude from red blood corpuscles and pretend they are spirochretes to know of an excellent description of them given by Dr. William Addison in the Transactions of the Microscopical Society of London, Vol. IX., 1861, p. 22, and Plate III. (in the Quarterly Journal of Microscopical Science, n.s., Vol. I.). His recipe for their production is to mix equal quantities of blood and a solution containing $1 \mathrm{gr}$. of common salt and $\frac{1}{2} \mathrm{gr}$. of bicarbonate of soda in two fluid drachms of water added to half a fluid ounce of good sherry wine. Port wine containing a grain of sulphate of quinine in half a fluid ounce was also efficacious; so was a mixture of one part of fresh urine with two or three parts of sherry wine. I am, Sir, yours faithfully,

Radlett, Feb. 28th, 1920.

A. E. BoycotT

\section{THE NEEDS OF AUSTRIAN MEDICAL FAMILIES.}

To the Eator of THE LANCET.

SIR,-May I make an appeal through your columns for the families of physicians in Vienna, especially the lecturer's in the University, who are not in private practice and are in dire distress? I have been aiding a number of friends and acquaintances for some time and have received to-day a letter from an eminent university professor, who is well known in England, in which he says: "Whatever you may have heard or read about our condition is far from exaggerated, but rather underestimates the state of our misery. The exchange alone (the English sovereign being formerly 24 crowns and now 950) is an indication of our extreme poverty. We hunger and freeze-for six weeks I have seen no coal-and it is a wonder that I can sometimes summon energy for work. Indeed, there is a danger of falling into a state of complete lethargy. ...... Being father of a family I venture to make use of your kind offer. If you could send us corned beef, flour, fat, and condensed milk, you would do us a great service."

Much is, no doubt, being done in England and essewhere for the very poor of Vienna; but, Sir, let us not forget our own colleagues, some of them famous and too proud to disclose their misery. THE LANCET has been so often the leader in appeals for charity, and is 